\section{From the Co-Editor}

Kevin A. Kerber, MD, MS

Innovations in Care Delivery strives to highlight articles that feature advances in care delivery in our Editor's blog, Editor's top 5 recommended reading, and Latest articles section. Periodically, we also include interviews with leaders in the field of health services research.

\section{Editors' Blog}

Amelia Boehme, $\mathrm{PhD}$, contributes a blog titled "Prophylactic antibiotic use in stroke patients," in reference to the article by Westerndorp et al., "Preventive Antibiotics in Stroke Study (PASS): A cost-effectiveness study," about ceftriaxone vs standard stroke unit care without preventive antibiotics therapy. In the primary publication of PASS, prophylactic ceftriaxone did not improve the modified Rankin Scale score at 3 months. Sensitivity analyses and 3 subgroup analyses also did not reveal a significant difference. Prespecified secondary outcomes were also not significant for mortality, pneumonia, or hospital length of stay, but were positive for overall infection rate ( $3 \%$ vs $7 \%$; mostly attributable to urinary tract infection, $1 \%$ vs $5 \%$ ). Dr. Boehme's conclusion was that the results do not support the use of preventive antibiotics. In the new study, Westerndorp et al. analyzed the effect of prophylactic ceftriaxone on the 7th and 8th prespecified secondary outcomes of quality-adjusted life-years and costs. These results were statistically significant, but Dr. Boehme recommends caution in interpreting these results based on the study's design (e.g., open-label), analytic methods, effect size, and potential adverse effects of more widely used prophylactic antibiotics.

\section{Editors' Top 5 Recommended Reading and Latest Articles}

Check out our collection of Neurology ${ }^{\circledR}$ articles related to innovations in care delivery. These 3 sections will keep neurologists up to date on innovations in care delivery within neurology and neurologic health services research. Current articles include "Effect of integrated community neurology on utilization, diagnostic testing, and access" by Elrashidi et al. ${ }^{2}$

\section{Other Don't-Miss Items}

Check out the May 1, 2018, Neurology podcast on the topic of drug pricing. Dr. Ted Burns discusses drug pricing with Ike Switlitz, a journalist for STAT. They discuss recent comments by Scott Gottlieb, the Food and Drug Administration (FDA) commissioner, regarding shared complicity for pricing practice. Switlitz also talks about his recent interview with Henry Waxman, author of the 1984 Hatch-Waxman Act, which established the way the FDA approves generic drugs.

For an interactive exchange on controversial clinical management topics, check out Neurology: Clinical Practice's "Practice Current" series. The series surveys neurologists about important clinical topics and publishes an overall commentary. Recent topics include the role of antibody testing in suspected autoimmune encephalitis, treating epilepsy in pregnancy, and diagnostic evaluation of cryptogenic stroke.

The American Academy of Neurology (AAN) recently offered the webinar course "iNeurology: Best Health IT Practices" that covered "the core functionalities of electronic health records, use [of] HIT to effectively report on payer programs, [and] identify[ing] tools to improve patient care."3 An earlier course, "Open Your Heart, Open Your Notes: A Guide to Patient Engagement," was offered in September 2017 to "familiarize [practitioners] with current patient engagement technology, employ tactics to enhance patient engagement, [and] explore the OpenNotes concept of sharing medical information." If you missed either of these courses, it is not too late to gain this useful information and earn CME by registering and viewing the recorded versions of the webinars on the AAN website.

\section{References}

1. Westendorp WF, Zock E, Vermeij JD, et al. Preventive Antibiotics in Stroke Study (PASS): a cost-effectiveness study. Neurology 2018;90:e1553-e1560.

2. Elrashidi MY, Philpot LM, Young NP, et al. Effect of integrated community neurology on utilization, diagnostic testing, and access. Neurol Clin Pract 2017;7:306-315.

3. Yu M, Lefberg S. 2017 Practice Management Webinars: iNeurology: Best Health IT Practices, November 7, 2017: Recording. In: American Academy of Neurology [online]. Available at: tools.aan.com/education/webcme/index.cfm?event=program:info\&program_id=221. Accessed May 10, 2018.

4. Weathers A. 2017 Practice Management Webinars: Open Your Heart, Open Your Notes: A Guide to Patient Engagement: September 12, 2017. In: American Academy of Neurology [online]. Available at: tools.aan.com/education/webcme/index.cfm? event=program:info\&program_id=219. Accessed May 10, 2018.

\section{○}

\section{Blog}

Read the Innovations in

Care Delivery blog for timely posts by the editors and invited guests on $\mathrm{Neu}$ rology articles. NPub.org/icdblog 


\section{Neurology}

\section{What's happening in Innovations in Care Delivery Neurology 2018;91;73 \\ DOI 10.1212/WNL.0000000000005874}

This information is current as of July 9, 2018

\section{Updated Information \&} Services

References

Permissions \& Licensing

Reprints including high resolution figures, can be found at: http://n.neurology.org/content/91/2/73.full

This article cites 2 articles, 2 of which you can access for free at: http://n.neurology.org/content/91/2/73.full\#ref-list-1

Information about reproducing this article in parts (figures,tables) or in its entirety can be found online at:

http://www.neurology.org/about/about_the_journal\#permissions

Information about ordering reprints can be found online:

http://n.neurology.org/subscribers/advertise

Neurology ${ }^{\circledR}$ is the official journal of the American Academy of Neurology. Published continuously since 1951, it is now a weekly with 48 issues per year. Copyright (O 2018 American Academy of Neurology. All rights reserved. Print ISSN: 0028-3878. Online ISSN: 1526-632X.

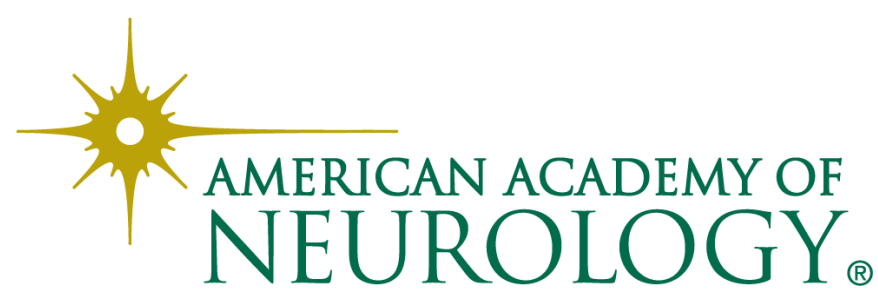

